\title{
Historical evolution of Medieval fauna in the Lower Segura, Alicante (Spain)
}

\author{
Trinitario FERRÁNDEZ VERDÚ \\ Sociedad de Estudios Biológicos Iberafricanos, \\ Avenida Teodomiro, 30, $1^{\circ} \mathrm{A}, \mathrm{S}-03300$ Orihuela, Alicante (Spain) \\ trinofv@gmail.com \\ Juan Antonio PUJOL FRUCTUOSO \\ Concejalía de Medio Ambiente, Ayuntamiento de Torrevieja, \\ Plaza de la Constitución, 1, S-03180 Torrevieja, Alicante (Spain) \\ torrevieja.japujol@gmail.com \\ Francisco ALMARCHA MARTÍNEZ \\ University of Alicante, Department of Contemporary Humanities, \\ Post AP, 99, S-03080 Alicante (Spain) \\ paco.almarcha@ua.es
}

Published on 29 December 2017

KEY WORDS

Historical development, wildlife,

Middle Ages,

Bajo Segura,

huerta,

Orihuela.

MOTS CLÉS

Évolution historique,

faune,

Moyen Âge,

Bajo Segura,

Orihuela.
Ferrández Verdú T., Pujol Fructuoso J. A. \& Almarcha Martínez F. 2017. - Historical evolution of Medieval fauna in the Lower Segura, Alicante (Spain). Anthropozoologica 52 (2): 203-214. https://doi.org/10.5252/az2017n2a5

\section{ABSTRACT}

The development and consolidation of the "huerta" (an agricultural system of irrigated fields) of Orihuela (Alicante, Spain) involved a series of historical changes in the ecosystem that have determined the configuration of the fauna associated with it in time. Focusing on the Medieval period $\left(13^{\text {th }}\right.$ to $16^{\text {th }}$ centuries), the sociocultural factors that caused these changes and their impact on fauna during this period are analyzed in this study. For this we have conducted a review of various sources that can reconstruct the most significant processes in the evolution of the landscape and wildlife of the area. To a large extent, the variety of environments that have historically been part of this territory, now much more homogeneous, are the source of its high animal diversity.

\section{RÉSUMÉ}

Évolution historique de la faune médiévale du Bas Segura, province d'Alicante (Espagne).

Le développement et la consolidation de la "huerta" (plaine irriguée et cultivée) de Orihuela (Alicante, Espagne) a impliqué une série de changements historiques de l'écosystème qui ont déterminé la configuration de la faune qui leur est associée à travers le temps. En se centrant sur l'époque médiévale (XIIIe-XVIe siècles), cette étude analyse les facteurs socioculturels qui ont provoqué ces changements et leurs répercussions sur la faune de la région pendant cette période. Dans ce but, nous avons peu à peu reconstruit les processus les plus significatifs de l'évolution du paysage et la faune du territoire. La diversité des milieux qui, au cours de l'histoire, ont fait partie de ce territoire, beaucoup plus homogène de nos jours, est en grande partie à l'origine de leur grande diversité animale. 


\section{INTRODUCTION}

The historical "huerta" of Orihuela (Alicante, Spain) covers an area defined by the limits of the province of Murcia to the west, the mountains of Orihuela, Callosa, Abanilla and Crevillente, to the north, and the small, undulating strip of territory of reliefs to the south that borders the flood plain to Guardamar del Segura (Gutiérrez Lloret 1995) (Figs 1; 2).

Although the "huerta", strictly speaking, does not extend beyond the spaces cultivated and irrigated artificially by man, the historical study of the fauna cannot be limited to the animal communities which, in a permanent and exclusive way, have occupied it. Animals move and they do so for a vast variety of reasons, including searches for resources, mating companions, and refuge or rest areas. These movements do not correspond to fixed temporal or spatial patterns, but vary depending on the ecology of each species, time of year, environmental conditions, and so on. If the analysis also has a historical perspective, the variability increases, since over time the biocenoses change as the habitats do, with the result that - in the same ecosystem - coexist elements of different, overlapping, and intertwined times (González 1981). Consequently, the historical study of wildlife in the "huerta" must, in addition to fauna that in one way or another have kept or maintained links with the agricultural system studied, include those of other environments with which it is or was associated physically or ecologically.

The evolutionary process of the structure and composition of crops in the Lower Segura since the 13th century has been parallel to that of the composition of their associated fauna. Hence, it is very difficult to assess to what extent a given biocenosis-associated agricultural space can be extrapolated to the past. If we consider the continuous process of change experienced by agricultural environments and the profound alterations that their environmental characteristics can undergo, the habits of many existing species may preserve only a vague reflection of past behaviors and adaptations. In this way, for example, many species that in past times had the abundant cereal fields as their feeding, or even nesting, grounds disappeared or were relegated to marginal spaces - such as salt marshes and slopes - after the transformation of cereal crops into tree orchards. Such was the case of many species of steppe birds or mammals such as wild boars. When considering all these conditions, the complexity involved in the deep and comprehensive analysis of the historical evolution of the fauna associated with a particular ecosystem is evident; more so if the ecosystem has undergone intense intervention by humans and is in an artificial and constant process of change.

Despite the existence of this feedback - sometimes positive, sometimes negative - between species and agricultural areas and the variation in their structures, constituent botanicals, or so, agricultural systems have a number of characteristics that are common. From an energy standpoint, their existence depends, wholly or partly, on human beings; their degree of structural complexity is always lower than that of most natural ecosystems; and we should not forget that agrarian systems are environments "created" by human activity.
Agricultural systems enjoy a number of incentives for wildlife colonization, which should be taken into account. Early after the transformation process, a small number of species is involved; the new crop behaves, in a way, as a newly emerged island, all niches are empty and ready to be occupied. At the same time, the low species diversity leads to lower levels of competition. Secondly, farming associated with a continuous human presence largely prevents the existence of predators, which is undoubtedly another major attraction. Moreover, the periodic episodes of super-abundance of food in the form of fruits or seeds, which also generally coincide with periods of higher trophic shortage in natural ecosystems, are a powerful lure for wildlife. Finally, although it does not constitute an incentive, strictly speaking, there is an enormous selection pressure in favor of the occupation of farming systems because of the unrelenting growth of the area cultivated throughout the planet, which induces wildlife to fill these spaces (Morales Muñiz 1996).

However, not all species make the same use of agricultural space. As a sort of example, we can establish a classification according to the time during which different species occupy these environments and would obtain up to five different types of temporary occupation:

- occasional agricultural species: species that occasionally can make use of agricultural land for trophic or climatic reasons, reproduction, etc.;

- seasonal agricultural species: species that occupy the agricultural space, systematically, at some point in their phenological cycle, usually for trophic or reproductive reasons;

- permanent agricultural species: species that have adapted their ecology to the agricultural system, to become sedentary; - agricultural facultative species: species in which a significant portion of the population (perhaps more than 50\%) may make permanent use of agricultural land;

- optional temporary agricultural species: species for which a significant part of the population (perhaps more than 50\%) may make temporary use of agricultural land, for trophic, reproductive, or climatic reasons.

Although this is a classification designed for birds, it would be possible to extrapolate it to other groups of fauna.

The "huerta" in the Lower Segura is generally considered to have its origin in the $13^{\text {th }}$ century (Barceló 1989). However, some authors place it hundreds of years before, between the $7^{\text {th }}$ and the $11^{\text {th }}$ centuries (Gutiérrez Lloret 1995). For this paper, we have considered a rather extended period of time, ranging from the late $12^{\text {th }}$ century to the middle of the $13^{\text {th }}$ century, thus leaving aside the question of its exact date of origin - which, in fact, is not decisive for the study of the fauna associated with the "huerta" ecosystem.

Moreover, not all zoological and animal species groups have aroused the same interest throughout history. Often, those without hunting interest - including a good number of amphibians, reptiles, birds, and mammals - were ignored in favor of a small group of game animals, mainly birds and mammals (Table 1) such as deer, fallow deer, roe deer, wild boar, ibex, ducks, and cranes. There are abundant written and iconographic references concerning the hunted or hunt- 


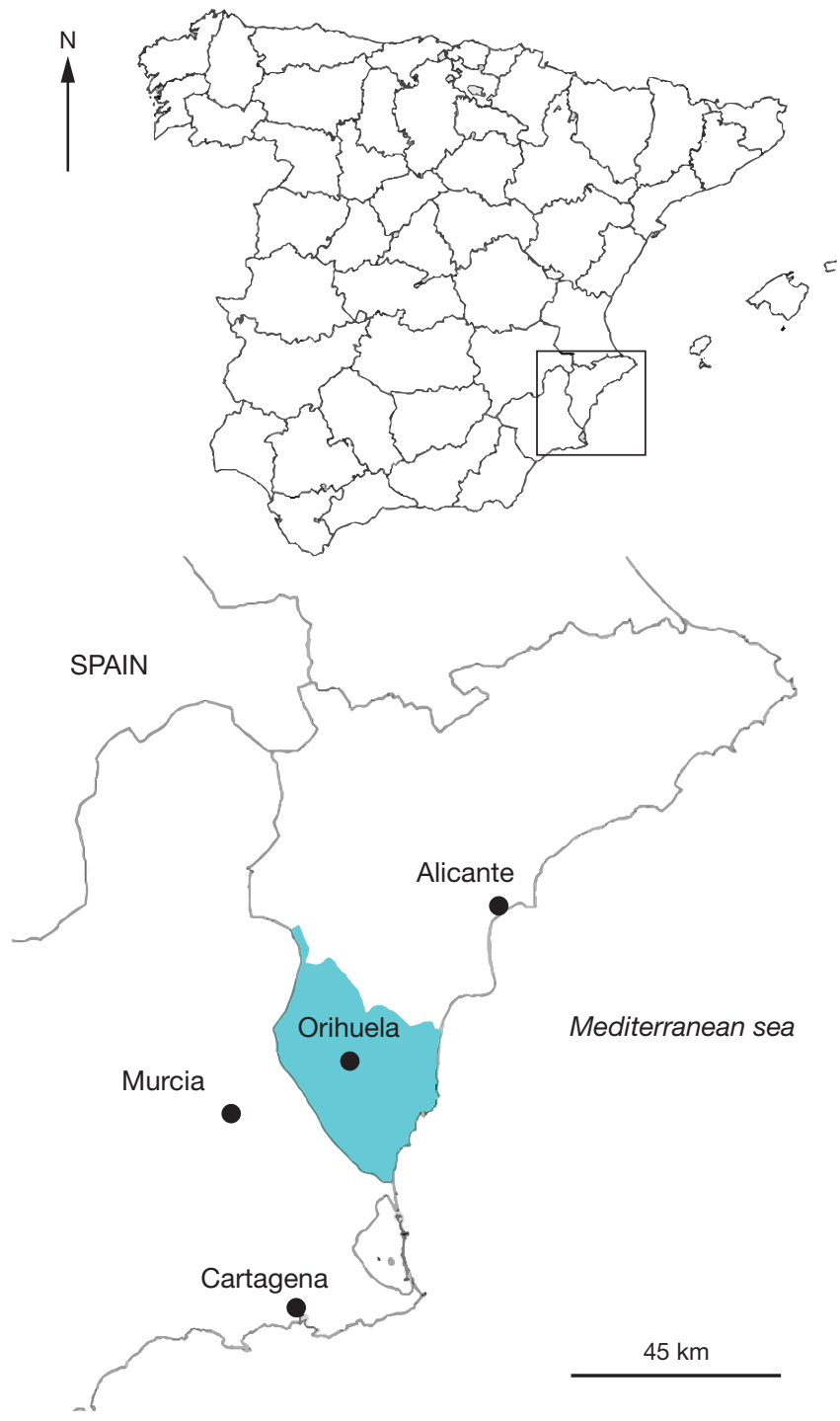

FIG. 1. - Location of Orihuela in the Iberian Peninsula.

ing species. Mentions of the mammals and birds concerned range from hunting treatises to the capitals of cloisters. The medieval, modern Renaissance, or Hispanic man was familiar with wolves, bears, foxes, deers, hawks, and cranes (Morales Muñiz 2000), but not with any other non-game species or those used in falconry of the Iberian fauna; this significantly reduces the spectrum of these species in the manuscripts and texts of those times.

\section{FROM THE LATE MIDDLE AGES TO THE MODERN (13 TH TO 16 ${ }^{\mathrm{TH}}$ CENTURIES)}

During the second half of the $13^{\text {th }}$ century and the first decades of the next, coinciding with the conquest of the lands now called Lower Segura, a process of land occupation, especially of the most fertile lands, occurred. The population increased: between six and nine million people are estimated to have been

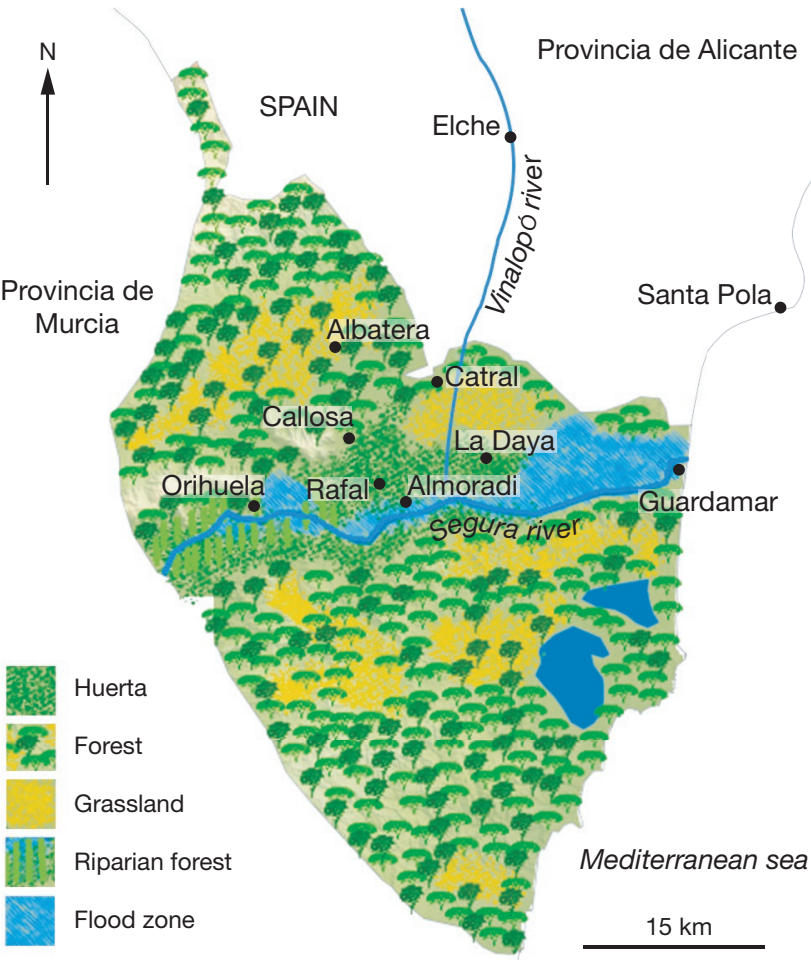

FIG. 2. - Mainly habitats and villages in Lower Segura in medieval ages.

living in the Iberian peninsula in 1300, giving it a density of 12 inhabitants $/ \mathrm{km}^{2}$ (Alonso 1995). In Orihuela lived, in the early $14^{\text {th }}$ century, around 8000 people (Barrio Barrio 2008). Associated with this growing population was the clearing of thousands of hectares of land for irrigated cultivation; just under 11000 hectares were transformed in the Lower Segura during the late Middle Ages (Barrio Barrio 2008). At the same time, new rural settlements sprang up around large cities - these would change forever the face of the landscape and with it, its structure and biodiversity. This process of colonization and transformation of large tracts of "virgin" land or the replacement of crops traditionally favored by the Muslims, such as olive tree orchards, by others, mainly cereals, had an obvious impact on animal communities: many species would be affected negatively, favoring others.

The increase in cultivated grasslands in the foothills and in the spaces surrounding the river made it possible for different species of small mammals and grain-eating birds to habitually forage and reside in these new, open areas of land, attracted by the high concentration of seeds and tender shoots. Graineating rodents and birds, along with some Alaudidae of steppe habits, such as larks and crested larks, successfully occupied these new habitats by increasing their populations. So much so, that some species would then be considered great enemies of cultivated fields; this was the case for the house sparrow (Passer domesticus (Linnaeus, 1758)), the "cucala" carrion crow (Corvus corone Linnaeus, 1758), and spotless starling (Sturnus unicolor Temminck, 1820). Killing them came to be rewarded by local authorities, and massive numbers were killed. In the chronicles of Valencia, for example, the death of 74630 birds 
TABLE 1. - Species of mammals and birds endemic to or native of the Iberian Peninsula, which could have occupied the Lower Segura in medieval times.

\begin{tabular}{|c|c|}
\hline Common name & Scientific name \\
\hline \multicolumn{2}{|l|}{ Mammals } \\
\hline Wild boar & Sus scrofa Linnaeus, 1758 \\
\hline Deer & Cervidae Goldfuss, 1820 \\
\hline Fallow deer & Dama dama (Linnaeus, 1758) \\
\hline Roe deer & Capreolus capreolus (Linnaeus, 1758) \\
\hline Ibex & Capra ibex Linnaeus, 1758 \\
\hline Wolf & Canis lupus Linnaeus, 1758 \\
\hline Bear & Ursus arctos Linnaeus, 1758 \\
\hline Fox & Vulpes vulpes (Linnaeus, 1758) \\
\hline Red deer & Cervus elaphus Linnaeus, 1758 \\
\hline Encebro, encebra or zebro & Equus hydruntinus Regàlia, 1907 \\
\hline Iberian ibex & Capra pyrenaica Schinz, 1838 \\
\hline Onagro & Equus hemionus Pallas, 1775 \\
\hline Goat & Capra hircus Linnaeus, 1758 \\
\hline Cabrera's vole & Microtus cabrerae Thomas, 1906 \\
\hline European beaver & Castor fiber Linnaeus, 1758 \\
\hline North African hedgehog & Atelerix algirus (Lereboullet, 1842) \\
\hline Common genet & Genetta genetta (Linnaeus, 1758) \\
\hline Iberian lynx & Lynx pardinus (Temminck, 1827) \\
\hline European rabbit & Oryctolagus cuniculus (Linnaeus, 1758) \\
\hline Sheep & Ovis Linnaeus, 1758 \\
\hline Cattle & Bos taurus Linnaeus, 1758 \\
\hline Mule & Equus asinus $\times$ Equus caballus \\
\hline Beech marten & Martes foina (Erxleben, 1777) \\
\hline Least weasel & Mustela nivalis Linnaeus, 1766 \\
\hline Wildcat & Felis silvestris Schreber, 1777 \\
\hline European badger & Meles meles (Linnaeus, 1758) \\
\hline Iberian hare & Lepus granatensis Rosenhauer, 1856 \\
\hline Black rat & Rattus rattus (Linnaeus, 1758) \\
\hline House mouse & Mus musculus Linnaeus, 1758 \\
\hline Grey rat & Rattus norvegicus (Berkenhout, 1769) \\
\hline Water vole & Arvicola sapidus Miller, 1908 \\
\hline Monk seal & Monachus monachus (Hermann, 1779) \\
\hline Otter & Lutra lutra (Linnaeus, 1758) \\
\hline \multicolumn{2}{|l|}{ Birds } \\
\hline Duck & Anatidae Leach, 1820 \\
\hline Crane & Grus Brisson, 1760 \\
\hline Hawk & Accipitridae Vigors, 1824 \\
\hline Lark & Alaudidae Vigors, 1825 \\
\hline
\end{tabular}

was recorded in 1410, at 20 "sueldos" per thousand; 91700 in 1411 and 127225 in 1412 (Furió 2001). In Murcia the council decided, in 1376, to collect half a penny per house in order to pay for volunteers to hunt birds in the fruit and olive groves near the city, at the rate of three "maravedis" per thousand (Torres Fontes 1981). The same happened in Orihuela, where the death of more than 1400000 birds is documented for the 1601-1743 period (Ojeda Nieto \& Ojeda-Martínez 2008). In general, farmers, shepherds, and hunters tried to keep under control the population of these birds, but when big flocks appeared it was the local authorities themselves who called on "cazadores de pardales o pájaros" (specialized hunters) or even organized hunting parties that lasted several days. Thus, in the hunting party that took place in Orihuela in 1683, a total of 154 men participated during four and a half days, each being paid 2.5 reales per day, and were provided with gunpowder and pellets (Archivo Municipal de Orihuela 1683).

The territories of some mammals decreased but others adapted, while the new agricultural areas were kept in use. Red deer (Cervus elaphus Linnaeus, 1758) and wild boar (Sus scrofa Linnaeus, 1758), did not overlook the resources

\begin{tabular}{|c|c|}
\hline Common name & Scientific name \\
\hline Crested lark & Galerida cristata (Linnaeus, 1758) \\
\hline House sparrow & Passer domesticus (Linnaeus, 1758) \\
\hline Carrion crow & Corvus corone Linnaeus, 1758 \\
\hline Spotless starling & Sturnus unicolor Temminck, 1820 \\
\hline Barn owl & Tyto alba (Scopoli, 1769) \\
\hline Black francolin & $\begin{array}{l}\text { Francolinus francolinus (Linnaeus, } \\
\text { 1766) }\end{array}$ \\
\hline Heron & Ardeidae Leach, 1820 \\
\hline Demoiselle crane & Anthropoides virgo (Linnaeus, 1758) \\
\hline Common crane & Grus grus (Linnaeus, 1758) \\
\hline Mallard & Anas platyrhynchos Linnaeus, 1758 \\
\hline Teal & Anas Linnaeus, 1758 \\
\hline Goldeneye & Bucephala S. R. Baird, 1858 \\
\hline Grey heron & Ardea cinerea Linnaeus, 1758 \\
\hline Purple heron & Ardea purpurea Linnaeus, 1766 \\
\hline Little egret & Egretta garzetta (Linnaeus, 1766) \\
\hline Bittern & Botaurus stellaris (Linnaeus, 1758) \\
\hline Black-crowned night heror & Nycticorax nycticorax (Linnaeus, 1758) \\
\hline Red-legged partridge & Alectoris rufa (Linnaeus, 1758) \\
\hline Common quail & Coturnix coturnix (Linnaeus, 1758) \\
\hline Greater flamingo & Phoenicopterus ruber Linnaeus, 1758 \\
\hline Peregrine falcon & $\begin{array}{l}\text { Falco peregrinus peregrinus Tunstall, } \\
1771\end{array}$ \\
\hline Barbary falcon & Falco pelegrinoides Temminck, 1829 \\
\hline $\begin{array}{l}\text { Mediterranean peregrine } \\
\text { falcon }\end{array}$ & Falco peregrinus brookei Sharpe, 1873 \\
\hline Large gyrfalcon & Falco rusticolus Linnaeus, 1758 \\
\hline Saker falcon & Falco cherrug J. E. Gray, 1834 \\
\hline Lanner falcon & $\begin{array}{l}\text { Falco biarmicus feldeggii Schlegel, } \\
\quad 1843\end{array}$ \\
\hline Buzzard & $\begin{array}{l}\text { Falco biarmicus erlangeri } \\
\text { O. Kleinschmidt, } 1901\end{array}$ \\
\hline Common wood pigeon & Columba palumbus Linnaeus, 1758 \\
\hline European turtle dove & Streptopelia turtur (Linnaeus, 1758) \\
\hline Eurasian golden oriole & Oriolus oriolus (Linnaeus, 1758) \\
\hline Eurasian eagle owl & Bubo bubo (Linnaeus, 1758) \\
\hline Little owl & Athene noctua (Scopoli, 1769) \\
\hline Eurasian scops owl & Otus scops (Linnaeus, 1758) \\
\hline Partridge & Phasianidae Horsfield, 1821 \\
\hline
\end{tabular}

that the appearance of new crops brought. Neither did the wolf (Canis lupus Linnaeus, 1758), an extremely plastic and intelligent animal that would continue ranging the Vega for centuries among cereals, olive trees, and vineyards - as it does even today in the fields of Castille.

These developments show the close relationship between socio-economic phenomena and the dynamics of faunal communities - which, in works on historical evolution, can be extremely difficult to track due to the lack of references and the unreliability of the existing ones. On a time scale of centuries, even millenniums such as the present one, social events help explain the faunal events of a given territory with higher resolution than the strictly natural. The species composition of any territory depends on the configuration of its landscape and its biogeographic history, but also very much on human history and its transforming capacity.

The transformation of the territory into new growing areas also led to the use of existing natural plants, which had to be removed as a pre-clearance step. This activity went well beyond the eventual collection of wood extracted from the new farmland; the systematic clearing of wood- 
land and scrub that took place during these centuries was a resource of the first order for the medieval economy of Orihuela, and is an important factor when assessing the evolution of the fauna in Orihuela in the late Middle Ages. The need for wood and charcoal was very high: for cooking, heating homes, or as basic building material. However, for centuries there was no control of the extraction or of the amount or type of species that could be cleared or should be respected, so the destruction of the forest was, in many cases, systematic and total (Ojeda Nieto 2007). During the years after the "Reconquista", as the Christian colonization proceeded, the lords and kings granted, together with land grants, permission to access the uncultivated areas, grasslands, and forests - then considered communal property - for the purpose of encouraging settlement. In the $13^{\text {th }}$ century, defined by the municipal councils and, occasionally, by the monarch himself, meadows ("dehesas") appeared: confined spaces where the neighbors could make charcoal or wood or take livestock to graze (Furió 2001). These were spaces for multiple uses and production activities, typically Iberian, in which cattle rearing and shepherding could be alternated with other forestry uses. The result of this was a landscape of not-very-dense woods, generally holly oak and cork oak, over pasture lands. Eventually, rules had to be dictated to govern or to ban the extraction of wood from the surrounding forests and mountains of Orihuela and some historians and scholars of the time recalled the tremendous lack of control. However, in a substantial part of the flooded plain, as well as on many slopes of the mountains and highlands, there was still scrub land and forest growing. This was a refuge for forest wildlife, which was disappearing or retreating increasingly into marginal areas as the exploitation of agricultural and forest spaces intensified.

\section{SOME SPECIES BECOME EXTINCT}

There are significant examples of species extinctions, both temporary and permanent, and recolonizations. One example among the large mammals is the bear (Ursus arctos Linnaeus, 1758), which today only lives in some Cantabrian mountains and the Pyrenees but which was not uncommon in the early $14^{\text {th }}$ century in the central and northwestern mountains of the region of Murcia (Alfonso XI 1975), even being mentioned two centuries later (Merino Álvarez 1981). After this date its presence is no longer recorded in the area, possibly due to its extinction in the region of Murcia at the end of the same century (Sánchez \& Esteve Selma 2000). Taking into account the large areas over which this plantigrade can range, it would not have been impossible to stumble across a bear in the mountains of La Matanza or Murada, where scrubland and forest still grew (Ojeda Nieto 2007), in contact with the "huerta" of Orihuela, as they are very close to the Murcia sightings. Horses and wild ungulates - such as, the encebro, encebra or zebro (Equus hydruntinus Regàlia, 1907), red deer, fallow deer (Dama dama (Linnaeus, 1758)), and roe deer (Capreolus capreolus (Linnaeus, 1758)) - were also common in the lands near the river and surrounding mountains during the centuries after the "Reconquista". Thus, as Merino Álvarez (1981) cites, during the reign of the Catholic Kings: "[...] the rest is filled with weeds in banks, meadows and groves; so frequent in the dry river beds, the rivers and lowland areas of Murcia, Orihuela, Totana and Cartagena, where with herbs the deer, 'encebra', roe deer and fallow deer were raised, of which some packs had passed to the islands off the coast." Often, these species were hunted and sold for consumption and the use of their skins; there are documentary references to the sales of the meat of Iberian ibex (Capra pyrenaica Schinz, 1838), wild boar, and red deer in the $14^{\text {th }}$ century Usually, the price of such meat was established by the Council of Orihuela, and usually increased in wartime when the availability decreased. So, in April 1361 the Council "ordena que la carne de cabrón montés [...] y puercos javalíes se venda a 10 dineros la libra” (orders the Iberian ibex meat [...] and wild boar to be sold at 10 coins the pound; Archivo Municipal de Orihuela 1361a), while at the end of May 1361 the same Council of Orihuela stated that "la carne de cabrón montés, javalí y de ciervo" (the flesh of Iberian ibex, wild boar and red deer) would not be sold at more than four coins the pound, under penalty of a fine (Archivo Municipal de Orihuela 1361b). In later years it also used the term "Salvagina" to refer generically to bushmeat (Nieto Fernández 1988) being sold in public markets.

Probably, under the name "Salvagina" was also included the meat of the encebro, encebra, onagro, or zebro, whose sale was not usually mentioned as such among the species available in butchers, although it was not often lacking in local markets (Clemente Ramos 2001). It was a kind of wild ass "[...] which were in a way like ash mares, hair the color of rats, a little sad, whinnied as mares and run so fast that there was no horse that could reach them", as described by Ortega in Relaciones topográficas de los pueblos de España in 1918 (Nores Quesada \& Liesau 1992). The animal that seems to fit best the direct descriptions made of the zebro between the $10^{\text {th }}$ and $16^{\text {th }}$ centuries is Equus hydruntinus, of which a wide fossil record exists throughout Europe from the Villafranquiense to the Bronze Age; precisely, its nearest records have been found in Spain (Nores Quesada \& Liesau 1992). Apparently, some specimens became domesticated and were ridden, although there is no clear evidence that the species reproduced in captivity (Nores Quesada \& Liesau 1992). Its flesh was highly appreciated, since the penalties established for unduly killing these animals were expressly imposed in some jurisdictions, becoming twice as much as those for red deer or wild boar (Sarmiento 1761). Its skin was also more expensive than that of red deer or goat; the loin (túrdiga) was used to make coats and shoes, which the Portuguese called zebrunos (Nores Quesada \& Liesau 1992). Don Enrique de Aragón Marquis de Villena attributed to its consumption the power to remove laziness, probably due to the speed and strength of the animal (Terrón Albarrán 1983). The Marquis himself tells us this in the Arte Cisoria o Tratado del Arte del Cortar el Cuchillo in 1423, a medieval culinary reference book, in which the unsurpassed quality of the meat of the encebra is praised and the author explains that eating it "removes laziness, slack, 
neglect or delay in actions or movements" (De Aragón 1766). Despite the absence of place names in Orihuela, we find them in Murcia and Alicante, so it is reasonable to consider the presence of this animal in the area until at least the $14^{\text {th }}$ century, when it appears, only mentioned by Alfonso XI (1975) in the Libro de las Montería, in the lands of Murcia. Thereafter, the species experienced a steady decline in its range, in parallel to its populations, disappearing completely in the Peninsula around 1540 in Roda, in the province of Albacete (Nores Quesada \& Liesau 1992).

Other species disappeared long before, as in the case of the Cabrera's vole (Microtus cabrerae Thomas, 1906) - of which, recently, traces have appeared in ancient pellets of barn owl (Tyto alba (Scopoli, 1769)) prospected in Cresta del Gallo (Murcia). This vole was hunted in the region of Murcia, and surely occupied the coastal areas of the Segura, downstream. Apparently, the remains found could date from Roman times (Tórtola \& Tórtola 2015). The European beaver (Castor fiber Linnaeus, 1758), of which remains are preserved in some sites in the southeast (Lull 1984), dwelt in all the major rivers of the Peninsula. So, surely, it could also have explored the shores of the Lower Segura, although we have no evidence of its presence. Its extinction in the Peninsula, apparently due to human pressure, took place around 1850 in the Douro River Basin.

Among the extinct species, the black francolin (Francolinus francolinus (Linnaeus, 1766)) is one of the most documented in the country (over 70 historical references were found by Jiménez Pérez [2013]). The great hunting and, particularly, gastronomic interest it enjoyed during the centuries in which it was present in Iberian lands, is undoubtedly the reason for its numerous references. Originally from the Middle East and Central Asia, the black francolin was introduced into Spain for hunting in the former territories of the Crown of Aragon, probably from the late $12^{\text {th }}$ century to the beginning of the $13^{\text {th }}$ century, although the first recorded mentions date from 1247, 1351, and 1368 (Maluquer \& Travé 1961; Jiménez Pérez 2013). There are only two explicit references to its presence in the lower Segura: one from Martinez Paterna, alluded to below, and one described by Vilar (1977) in Historia de la Ciudad de Oribuela: "In 1435, for example, the corporation punished with the exorbitant fine of one thousand florins those who hunted the black francolin chickens released by the noble Pere Rocafull." However, references abound in Murcia and Valencia, confirming its presence between the $13^{\text {th }}$ and $18^{\text {th }}$ centuries, after which time, due to heavy hunting pressure on the species, it eventually disappeared.

The black francolin was considered for centuries an extraordinary hunting quarry and an excellent choice of food; authors like Cervantes and Quevedo refer to it as a delicacy (Jiménez Pérez 2013). Even the king of Castile himself, John II, in a letter to the commander of Lorquí, Sancho de Davalo, in January 1454 and after having tried them, asks to be sent a dozen, six males and six females, with the obvious intent of multiplying them for consumption (Torres Fontes 1974). It was certainly this gastronomic quality, coupled with the ease of capture due to its lack of suspicion, which led the francolin to extinction.
But, in addition to specific extinctions, there were also interesting animal translocations on a large scale, such as the North African hedgehog (Atelerix algirus (Lereboullet, 1842)) - brought from North Africa by the Almohads during the $12^{\text {th }}$ and $13^{\text {th }}$ centuries (Morales Muñiz \& Rofes 2008) - and probably also the common genet (Genetta genetta (Linnaeus, 1758)), although some authors date its arrival before the Arab invasion of the Iberian peninsula.

\section{ABOUT LYNX AND WOLVES}

With the ongoing economic expansion and after successive divisions of land for cultivation, other cereal species such as rice (Parra Villaescusa 2013) were introduced. Many of the marginal areas left to fend for themselves for decades would be colonized or occupied from the $13^{\text {th }}$ and $14^{\text {th }}$ centuries onwards. This brought a new transformation of the landscape and its wildlife. The inclusion of rice in areas hitherto uncultivated partly transformed faunal communities by introducing new areas flooded with freshwater, at least temporarily, in a coastal environment of wetlands, marshes, sporadic upwellings of water, and river overflows. However, this process of change and expansion of crops had specific and sometimes prolonged periods of decline, as occurred after the plague of 1348. In the Orihuela of the $13^{\text {th }}$ century, domestic herds hardly exceeded a few hundred heads, but the depopulation and consequent reduction in cultivated areas caused by this and other episodes of fever marked a significant increase in the land under pasture, which resulted in a hitherto unknown growth of livestock, quite undemanding in labor. From that time many herds consisted of well over a thousand or more heads. Undoubtedly, these turning points in a general process of economic and agricultural expansion had an impact on the composition and abundance of the medieval low-faunal community; one only needs to think of predators such as wolves, for which the rise of cattle numbers in the field represented a greater availability of resources in parallel to a potential increase in their own populations. However, not all changes were positive.

The "huerta" of Orihuela we now know and that at that time reached the very edge of the coast was, during these centuries, a mosaic of small orchards and cereal (especially on the banks of the river) and grazing areas, scrub, and thickets of more or less extensive woodland, which - as they advanced towards the river mouth - turned into salt marshes with large flooded spaces (Gutiérrez Lloret 1995; Azuar Ruiz 1999), which served as hunting grounds and shelter for a large community of Iberian carnivores. This was the case of the wolf, and probably the Iberian lynx (Lynx pardinus (Temminck, 1827)).

There are, to our knowledge, no written records of the presence of Iberian lynx in the Lower Segura in medieval times. However, there are references to its presence in the southeast from the Pleistocene until 1960 (Garrido-García 2008; Pantoja et al. 2011) and in the north of Alicante during the Magdalenian period (15000 and 8000 years BC) (Real Margalef 2012), while in the Sierra de la Pila (Fortuna, Murcia) and Escalona (Orihuela, 
Alicante, and Murcia) there are clear indications of its presence until the $20^{\text {th }}$ century - if you rely on oral tradition, although there are no documented quotes. Despite the fact that the differences in their ecological aspects (selection of habitats, prey type, and so) are marked, Iberian lynx and wolves certainly shared hunting and foraging territories of both floodplains and orchards, and of mountains and forests nearby. But, more relevant to their historical development than their ecological differences, although because of them, are the different perceptions that agricultural and pastoral societies have of the two species. The Iberian lynx was, and is, basically a killer of rabbits, and - although the European rabbit (Oryctolagus cuniculus (Linnaeus, 1758)) was an animal quoted as being hunted and was probably a key element in the subsistence economy of many families of the time - the consequences of this competition for resources between humans and Iberian lynx were never dramatic for the lynx, at least during those centuries. Men and Iberian lynx lived during the Middle Ages and we are not aware of a conflictive relationship, as did exist between men and wolves. Numerous entries in the books of Claverías, in the Historical Archives of Orihuela, record payments to be made for the death of wolves to shepherds and farmers, and even professional hunters, "casadores of llops". The wolf was the animal which created the widest mistrust, fear, and hatred among men, and the inhabitants of the Lower Segura were no exception. As an example, their treatment of living wolves reaching the city of Orihuela will suffice: "[...] they were given the final blow; they cut their ears and threw them into the river. But with the small ones, which according to the documents were always alive, the treatment was more ruthless, as they were dumped alive into the water and not before cutting off their ears, unless they were milk wolves. The order was always: 'llansar els chiquets al Riu' (throw the small ones into the river)" (Ojeda Nieto 2005).

There are sociocultural reasons for this treatment, rooted in ancient myths and legends in which the wolf was always a cruel and harmful animal which must die. These are stories that have their origin in environmental disputes and competition for food, consistently maintained by both species over time. Competition for wildlife such as red deer and Iberian ibex has been a constant throughout history, but the time when domestic livestock became a key component of the human diet marked the turning point in the relationship between the two species. The decline in stocks and the expansion of wild predators of livestock caused an exponential increase in human-wolf conflicts. In Orihuela alone, for the livestock census conducted on the occasion of the Courts of Monzón of 1510, a herd of 5566 heads of sheep, goats, and cattle was recorded, notwithstanding the pigs, mules, and poultry (Hinojosa Montalvo 1992). To shepherds, subject to a subsistence economy, cannot be attributed the open declaration of war on wolves. From the $15^{\text {th }}$ century, the death of livestock caused by the large population of Segura wolves led to a systematic and thorough killing of wolves - not only in Orihuela, but in many other towns, like Elche, Castellón, or Alcoy, in which their presence was recorded. Between 1421 and 1486, 43 wolves were killed in Orihuela, as shown by the records. And in the first decade of 1600 , in just eight years, the figure reached 245, an average of 30 heads per year (Ojeda Nieto 2005). In Elche, wolves were captured in the orchards, even at the foot of the walls (Hinojosa Montalvo 1992). In the Extremadura mountain ranges of Montánchez and San Pedro, historically lands of wolves where the species was present until well into the $20^{\text {th }}$ century, 26 wolves were killed between 1545 and 1555 (Clemente Ramos 2001), which gives us an idea of how abundant they might have become in the medieval Orihuela administrative district. Today, only a place name such as "El Paso del Lobo" in the Sierra de Orihuela, the mountain pass "Seco del Lobo" in Escalona, "Canta Lobos" for a well in the middle of the "huerta", "Peña del Lobo" in Santa Pola, or "Las Piedras del Lobo" in Elche remind us of the presence of the species (Hinojosa Montalvo 1991; Sanchez Pérez \& Alonso de la Cruz 2004). Nevertheless, the wolf was not rejected as a source of medicinal remedies and cures. Alfonso XI recalls, in the Libro de la caza (Book of Hunting), that wolf grease was used to help the hair grow back after an episode of scabies; in Cartagena, children who were teething had a bag with wolf teeth hanging from their necks to make theirs grow strong (Rabal Saura 2006).

Other carnivores like beech marten (Martes foina (Erxleben, 1777)), least weasels (Mustela nivalis Linnaeus, 1766), wildcat (Felis silvestris Schreber, 1777), and European badger (Meles meles (Linnaeus, 1758)) populated the medieval Orihuela, as they do today, although we have no written records. Usually, these species would not have been easily detectable, but were considered vermin and would likely have been culled regularly. Very elusive in their nocturnal habits, these species would range between the river and the mountains, taking much care not to be seen by shepherds and peasants, who would not pass up the opportunity of killing them. Much more visible and perhaps abundant, despite also being considered vermin, was the red fox fox (Vulpes vulpes (Linnaeus, 1758)); with its nocturnal penchant for pens and chicken coops, it surely would have been the greatest scourge of the "huertanos" in the Vega, along with the genet.

\section{THE LITTORAL WETLAND AND MARSH AREAS}

While the community of large and medium-sized mammals was plentiful and dotted around the orchards and fields of medieval Lower Segura, species linked in one way or another to wet areas, salt marshes, and rivers were much more conspicuous. It should not be forgetten that flooded or marshy spaces occupied much of the lowlands of Segura - including part of the land that subsequently emerged and today is dry, as well as Santa Pola, Elche, and Albatera. Also, the Segura and Vinalopó rivers did not deposit their waters in the sea, but in the great lake that reached the gates of Almoradi (Azuar Ruiz \& Gutiérrez Lloret 1999) (Fig. 2). The presence of marshes in the late Middle Ages is documented in the area of the Puerta de Murcia and La Moquita (near the Castilian border) and in Albatera, Catral, La Daya, Almoradi, Callosa, and Rafal, most of them on the left bank of the river 
(Parra Villaescusa 2013) (Fig. 2). This is the description that Gutiérrez made of the boundaries of the Bajo Segura lake space at the end of the $13^{\text {th }}$ century: "[...] all the space that includes [...] must have been a wetland formed by authentic permanently flooded ponds, such as the Hondo de Elche, areas with sheets of shallow water and fluctuating levels, forming marshes and salt marshes themselves. This fluctuating space should extend north from Santa Pola to Albatera, bordering the alluvial fan of the Vinalopó river and the glacis of the Sierra de Crevillente; the west should follow the curve of ten meters. (contour line $10 \mathrm{~m}$. above sea level) from southern Albatera to meet the Segura River, bordering Almoradí and Daya Vieja, probably located on the edge of the flooded area. In the center of this vast lagoon, separated by a line of mobile dunes, the Sierra del Molar stood, which should give the appearance of a peninsula in the middle of the marsh."

The dawn of the "Huerta" of Orihuela, between the 10th and $11^{\text {th }}$ centuries, gave rise to the decline of the production system based on the use of wetlands and marsh areas, to be replaced by the development of an agricultural area that would spread from the city to the limits of the wetland. This meant that most settlements surrounding the limits of the flooded areas or inside, occupied since Roman times, disappeared from the $13^{\text {th }}$ century onwards (Furió 2001). Few would venture to live in this inhospitable and extreme landscape of mosquito infested lagoons and impenetrable, sterile salt marshes, beyond those groups who, by their particular situation of poverty and marginalization, were forced to. The lack of fertile land, and the risk of contracting deadly diseases such as malaria, kept the limits of the lower section of the river Segura uninhabited for centuries. However, these forgotten and marginal lands offered some opportunities to their scarce settlers, such as fishing and waterfowl hunting. Herons, cranes, and ducks, well known at the time for their hunting interest, should have been abundant in these riparian and marsh environments. So tells us Juan Manuel (Baist 1880: 78), in the Book of Hunting: "Lagoons and marshes of Caral, Barcos and Almuradí of Ladaxa and of Cabeçuelos they say belong to Don Manuel, and in the ditch that Don Manuel had done in Albadera, in all these places here are many such herons and many Bitores, but they are very hard to take with falcons. And in the shores of these marshes until Crivillén, sometimes there are no ducks that can be hunted with falcons, and in all these fields here are many cranes and it is good for hunting. In Guardamar there's no shore but the sea and the river Segura, and herons are hard to hunt with falcons, and there are neither ducks nor cranes that can be hunted. In Orihuela there are many herons in the river Segura, and sometimes in a ditch that is outside the village, which is the door to Murcia. And says don Johan who already failed, and it was very expensive with the falcons, because a mule died also. From Orihuela till Murcia, up the Segura River, here are many herons, but they are very hard to kill with falcons because it is a big river and there is no pass and lots of trees and many ditches" (Fig. 2).

Of these species, only the crane is not present today permanently (cited only as a vagrant) in the region. Given the medieval presence of the demoiselle crane (Anthro- poides virgo (Linnaeus, 1758)) in some areas of the Iberian Peninsula (Morales Muñiz \& Morales Muñiz 2001), is it possible that the text also refers to it, together with the common crane (Grus grus (Linnaeus, 1758)). One might suppose that the generic sightings for "ducks" and "herons" would include the mallard (Anas platyrhynchos Linnaeus, 1758) and probably some other species of ducks, teals, and goldeneyes, although the latter are identified by name in another passage of the book.

The generic term "herons" probably refers mostly to the highly appreciated grey heron (Ardea cinerea Linnaeus, 1758), although - no doubt - the elusive purple heron (Ardea purpurea Linnaeus, 1766) and the little egret (Egretta garzetta (Linnaeus, 1766)) existed and were hunted. The quote also refers explicitly to the bittern (Botaurus stellaris (Linnaeus, 1758)), although not included in the group of the herons as it is today. Probably, the same can be said for the black-crowned night heron (Nycticorax nycticorax (Linnaeus, 1758)) - which, although not cited, certainly must have existed in the wetlands on which the Infante hunted. Don Juan Manuel also talks about the existence of red-legged partridge (Alectoris rufa (Linnaeus, 1758)), common quail (Coturnix coturnix (Linnaeus, 1758)), and greater flamingo (Phoenicopterus ruber Linnaeus, 1758) in Villena, species that were present in the Bajo Segura as they are today.

The hawks (Falco spp.) or "falcones" mentioned were trained for falconry and were not wild, as is clear from the text. In the late Middle Ages experts already had deep knowledge of the biology and habits of these birds of prey, distinguishing the different species and breeds - which were handled with ease. Falconry was a favorite pastime of kings, princes, and nobles, being a real passion in the case of Infante Don Juan Manuel. The falconry tradition continued in these lands well into the 16th century. At the time, several types of hawk, currently considered as different species or subspecies, were known. Moreover, the traffic of these highly prized animals was very important; they came from central and northern Europe, the Middle and Near East, and North Africa. One of the most appreciated hawks was the peregrine falcon, and several subspecies in particular came to the Iberian Peninsula: peregrine falcon or "neblís" (Falco peregrinus peregrinus Tunstall, 1771) from Europe and Asia, and also present in Spain, the Barbary falcon or "tagarotes" (Falco pelegrinoides Temminck, 1829) of North Africa and the Arabian Peninsula, and the Maltese falcon or Mediterranean peregrine falcon (Falco peregrinus brookei Sharpe, 1873), distributed in Mediterranean Europe, including all the Iberian Peninsula and islands such as Sardinia and Mallorca. The large gyrfalcon (Falco rusticolus Linnaeus, 1758), with white plumage, came from the northern regions of the European taiga and tundra, while saker falcons (Falco cherrug J. E. Gray, 1834) were caught in Europe, Asia, and Africa. Also in high demand were lanner falcons (Falco biarmicus feldeggii Schlegel, 1843) and the other subspecies called buzzards (Falco biarmicus erlangeri O. Kleinschmidt, 1901), which were brought from North Africa. Of this latter species says Pero López de Ayala (1959) 
in his Libro de la Caza de las Aves (Book of Fowling): "And being in Alicante, which is in Aragon shore of the sea came a ship coming from the Barbary and brought many buzzards and bought them and the lord and master of the ship he gave me one that said he was 'entreceli', and indeed, the waist, hands and face was 'tagarote', more feathers and its color was that of buzzards, and I had it for long; I did not bother to make him anything but a retriever and this is what I do very well, because it was very light." For the Mediterranean peregrine falcon, "seahawks" or "baharis", no record of their existence in the area of Orihuela exists. Jaime II ordered here, and on the island of Mallorca, the catching of chicken hawk - which, once trained, fetched high sums of money (Vilar 1977; Hinojosa Montalvo 2006). Eagles, falcons, hawks, and goshawks were also cited, but in a generic way and always in relation to their hunting qualities in the art of hawking.

Many other species of birds would visit or reside in those ancient marsh areas, but - due to their scarcity or temporary or limited hunting interest - were not mentioned in the texts of the time. Only a few species more, like common wood pigeon (Columba palumbus Linnaeus, 1758) or European turtle dove (Streptopelia turtur (Linnaeus, 1758)), are listed by their common name (Torres Fontes 1974).

\section{THE ORIOL BIRD AND OWLS}

From medieval Oriola came the Flag of the City (Enseña of Oriol): a banner topped by a bird gilt in silver, the oriol, the name given in Valencian to the Eurasian golden oriole (Oriolus oriolus (Linnaeus, 1758)). Although what we see on the city seal is actually a mythical bird and it gradually underwent a profound metamorphosis in its various representations, surely the Eurasian golden oriole was an abundant bird in the spring river banks and medieval groves of the Segura. The coincidence in the name derives from the common allusion which is made in the two terms to gold. Most writers do derive the first place-name of Orihuela from the Latin words Auri olla, i.e. pot or container of gold, supposedly due to the abundance of gold in this land, extracted in Santomera and the mountains of Orihuela. For its part, the oriole is a handsome black and golden (deep yellow) bird and Linnaeus named it in 1758 with the Latin term Oriolus, a clear reference to the color of its plumage.

Particularly striking is the lack of mentions of nocturnal predators such as the owl. They are not cited in this geographical context, even as medieval Aragonese words like "Bubo" or "Bobon". The Eurasian eagle owl (Bubo bubo (Linnaeus, 1758)), barn owl (Tyto alba (Scopoli, 1769)), little owl (Athene noctua (Scopoli, 1769)), and Eurasian scops owl (Otus scops (Linnaeus, 1758)) were present as they are today, and it is reasonable to think that they were abundant in the medieval Lower Segura, given the existence of suitable habitat and prey. However, since they are not birds prized for consumption or falconry, they were not referred to in the hunting texts of the time.
TABLE 2. - Species of reptiles, amphibians, and fishes endemic to or native of the Iberian Peninsula, present in the Lower Segura today and which could have occupied the lowlands of the Segura in Medieval times.

\begin{tabular}{|c|c|}
\hline Common name & Scientific name \\
\hline \multicolumn{2}{|l|}{ Reptiles } \\
\hline Montpellier snake & $\begin{array}{l}\text { Malpolon monspessulanus (Hermann, } \\
\text { 1804) }\end{array}$ \\
\hline Western false smooth snake & Macroprotodon brevis (Günther, 1862) \\
\hline Ladder snake & Rhinechis scalaris (Schinz, 1822) \\
\hline Horseshoe whip snake & $\begin{array}{l}\text { Hemorrhois hippocrepis (Linnaeus, } \\
\text { 1758) }\end{array}$ \\
\hline Southern smooth snake & Coronella girondica (Daudin, 1803) \\
\hline Viperine snake & Natrix maura (Linnaeus, 1758) \\
\hline Iberian worm lizard & Blanus cinereus (Vandelli, 1797) \\
\hline Bedriaga's skink & Chalcides bedriagai (Boscá, 1880) \\
\hline Spanish pond turtle & sa (Schweigger, 1812) \\
\hline Spanish psammodromus & $\begin{array}{l}\text { Psammodromus hispanicus Fitzinger, } \\
1826\end{array}$ \\
\hline Spiny-foote & $\begin{array}{l}\text { Acanthodactylus erythrurus (Schinz, } \\
\text { 1833) }\end{array}$ \\
\hline Iberian wall lizard & $\begin{array}{l}\text { Podarcis hispanicus (Steindachner, } \\
\text { 1870) }\end{array}$ \\
\hline $\mathrm{Be}$ & Timon nevadensis (Buchholz, 1963) \\
\hline n wall gecko & uritanica (Linnaeus, 1758) \\
\hline Latas & Vipera latastei Boscá, 1878 \\
\hline \multicolumn{2}{|l|}{ Amphibians } \\
\hline Common midwife toad & Alytes obstetricans (Laurenti, 1768) \\
\hline Common toad & Bufo bufo (Linnaeus, 1758) \\
\hline Natterjack toad & Epidalea calamita (Laurenti, 1768) \\
\hline Iberian Waterfrog & $\begin{array}{l}\text { Pelophylax perezi (López-Seoane, } \\
\text { 1885) }\end{array}$ \\
\hline
\end{tabular}

\section{Fishes}

Sedentary/seasonal marine species

European seabass Dicentrarchus labrax (Linnaeus, 1758)

Big-scale sand melt Atherina boyeri Risso, 1810

Flathead grey mullet Mugil cephalus Linnaeus, 1758

Thickclip grey mullet Chelon labrosus (Risso, 1827)

Golden grey mullet Liza aurata (Risso, 1810)

Leaping mullet

Boxlip mullet

Common goby

Sedentary marine species Black-striped pipefish

Migratory species European eel

Liza aurata (Risso, 1810)
Liza saliens (Risso, 1810)

Oedalechilus labeo (Cuvier, 1829)

Pomatoschistus microps (Krøyer, 1838)

Syngnathus abaster Risso, 1827

Anguilla anguilla (Linnaeus, 1758)

Limnetic species

Freshwater blenny

Salaria fluviatilis (Asso, 1801)

Continental species

Andalusian barbel

Iberian chub

Iberian toothcarp

Luciobarbus sclateri (Günther, 1868)

Squalius pyrenaicus (Günther, 1868)

Aphanius iberus (Valenciennes, 1846)

\section{FROGS, TOADS, AND RATS}

Besides birds, the lowlands of the river Segura host a sizeable community of amphibians, reptiles, and fishes. Below are listed the endemic or native species of the Iberian Peninsula, present today and therefore very likely part of the medieval fauna of the Lower Segura (Table 2).

Six species may be distinguished:

- The Spanish pond turtle. It is present in the area. Von den Driesch (1975) refers to the abundance of water turtle shells in the Saladares of Arneva; we think they are Spanish pond turtles; - The Lataste's viper. It seems to be present in the Lower Segura today; the Atlas and Red Book of Amphibians and Reptiles of 
Spain (Pleguezuelos et al. 2002) puts it in closely proximate territories. In the 1980s there was a sighting in the Swamp of Elche (Fernández \& Fidel 2004). It is also cited in the report on biodiversity in the town of Elche (Aranda \& Maciá 2010). - The common midwife toad. It is not present in the Bajo Segura today (Fernández 2013), although in previous years dating to 2000 it was located in territories of close proximity. In the Atlas and Red Book of Amphibians and Reptiles of Spain (Pleguezuelos et al. 2002), it is mentioned as existing in the area, and it features in the report on biodiversity in the town of Elche (Aranda \& Maciá 2010). Recently, it was found in a small town north of the town of Orihuela, specifically Barbarroja (Ruiz pers. comm.).

- The European eel. It is the only species mentioned in historical texts as being present between the $16^{\text {th }}$ and $19^{\text {th }}$ centuries in the lower reaches of the river Segura (Mas Hernández 1986). Regarding the $15^{\text {th }}$ century, it is cited by Torres Fontes (1974) in his Medieval Ornithology of Murcia.

- The Iberian chub. Although not currently present in the Lower Segura, there is evidence of its former presence until 1970 (Elvira Payán \& Doadrio Villarejo 1989).

- The Iberian toothcarp. Sighted in the Hondo de Elche, Hondo Amoros, Salinas de Santa Pola, Salinas del Pinet, and Villena (Villwock \& Planelles-Gomis 1999).

As evidenced in other parts of the text, the knowledge of animals valued by the people of that time was based largely on the interest awakened by hunting the species, being especially important when they were hunted for the domestic economy. More than big game - for which it was necessary to have weapons and sometimes special permits, to which not everyone had access - ordinary villagers hunted partridges, Iberian hares (Lepus granatensis Rosenhauer, 1856), and European rabbits, as is recorded in numerous written references. From the hunting interest the knowledge of animals was born and from this the assignment to them of virtues or defects derived from the human condition, which was the medieval way of interpreting the behaviors and biological strategies of the wildlife with which people lived. Thus, Europeans rabbits and Iberian hares were - for medieval "oriolanos" - symbols of fertility and sexual debauchery, which demonstrates their abundance, and were related with lust.

The relationship maintained with other species was very different; for instance, rodents such as the black rat (Rattus rattus (Linnaeus, 1758)) and the house mouse (Mus musculus Linnaeus, 1758), which had arrived in Spain from Asia a while back. Transmitting very serious diseases such as the bubonic plague, the black rat was hated for its parasitic nature and as a predator of crops. For years, mass killings were carried out to try to eradicate it, but of doubtful efficacy. Easy access to crops and organic remains was bound to increase with human population density, and this maintained for centuries important populations of black rats and house mice in hamlets, villages, and towns in the Vega Baja district. With regard to the grey rat (Rattus norvegicus (Berkenhout, 1769)), we do not know if it was present or, in any case, its importance in the transmission of the bubonic plague and other diseases. Apparently, this species did not reach Spain - and probably the Lower Segura - until the end of the $19^{\text {th }}$ century (Sanchez \& Esteve Selma 2000), although a study by the University of Granada on the wildlife of Macael (Almería) mentions it in Nazari times (13 $3^{\text {th }}$ to $14^{\text {th }}$ centuries) (Riquelme Cantal 1992). The water vole (Arvicola sapidus Miller, 1908) would have been plentiful, and it is present even today in some parts of the upper Segura, but it disappeared from the region of Murcia and the lower Segura, it seems, at the end of the $19^{\text {th }}$ century or in the early decades of the $20^{\text {th }}$; even before the great changes in the landscape and the episodes of severe pollution in the 1960s (Tórtola \&Tórtola 2015). However, being a herbivore and closely linked to the waterways, it should not pose a great threat to people and crops.

\section{AQUATIC MAMMALS: THE OTTER AND SEAL}

These two species, sadly missing today, were found dotted around the banks of the Segura and the coastal area around its mouth until relatively recent times. One is the monk seal (Monachus monachus (Hermann, 1779)), abundant and sedentary in past times on the coasts of Alicante and the Region of Murcia; until the 19th century it was present on almost all the appropriate coasts and islands of the Mediterranean and was cited as being present in Playa Ferrís (Torrevieja) in 1965 (Gonzalez \& Avellá 1989; Sánchez \& Esteve Selma 2000). Although we cannot be sure that -500 years ago - seals swam off the Orihuela coast, their endemic nature, their presence until recently, and the existence of certain place names in the area (in Torrevieja there was a "Lobo Marino" cove, referred to by José Tormo, Bishop of Orihuela, in 1789) (Pujol 2012) allow us to speculate on their more than likely presence in medieval times.

The other is the otter (Lutra lutra (Linnaeus, 1758)), for whose presence in the Lower Segura there are no written records from the medieval period, although it should have been common in the river. Chapman \& Buck (1901), in The Unexplored Spain, mention it in the royal documents of Jaime I (1208-1276) as being present in the Albufera of Valencia, next to francolins, red deer, and Iberian ibex. It also appears in the Albufera at the beginning of the $16^{\text {th }}$ century, as mentioned by Escolano (1611), who also provides the traditional Valencian name "llúdria".

From the $13^{\text {th }}$ to the $16^{\text {th }}$ centuries there were numerous droughts and floods that devastated crops, and pests, such as the locust, devastated crops. Some early episodes of the Little Ice Age, around the $16^{\text {th }}$ century, reduced temperatures significantly; there were very serious epidemics of plague and war that decimated the population, as well as massive rural-urban and vice versa migrations, echoed in history. We can imagine that all these events affected, in many ways and in varying degrees, the animal community and the population dynamics. However, there is no record of the extent to which these historical events affected the wildlife. 


\section{CONCLUSION}

The birth and expansion of the "huerta" of Orihuela have been the product of a series of economic, social, and cultural events that have shaped the landscape and the fauna associated with it. The interrelationship between human beings and the environment and the animal world during the Middle Ages brought about a natural world in accordance with human needs, a nature as free as possible of "vermin", while the systematic hunting of other species prized for their meat equally resulted in their extinction. Similarly, the changes in the ecosystem began a process of homogenization of the fauna, which, however, still retains today some traces of its former wealth.

\section{Acknowledgements}

We express our gratitude to the two anonymous referees for their helpful comments and suggestions.

\section{REFERENCES}

Alfonso XI 1975. - Libro de la Monterías del Rey D. Alfonso XI con un discurso y notas del Excmo. señor José Gutiérrez de la Vega. Velásquez, Madrid, 288 p. (Coll. Biblioteca Cinegética Española; 3). [1 ${ }^{\text {st }}$ ed. 1877]

AlONSO J. 1995. - Una tierra abierta. Materiales para une historia ecológica de España. Ed. Compañía Literárica, Madrid, 355 p.

Archivo Municipal de Orinuela 1361a. - Actas Capitulares 1, Capitular de 1361, f. 44v.

ArChivo Municipal de Orinuela 1361b. - Actas Capitulares 1, Capitular de 1361, f. 8.

ArChivo Municipal de Orinuela 1683. - Capitular de 1683 , Lib. 699, 17 de mayo de 1683.

ARANDA J. C. \& MACIÁ S. 2010. - Biodiversidad del municipio de Elche. Ayuntamiento de Elche, Elche, 122 p.

AzUAR RuIZ R. 1999. - El paisaje medieval islámico de las tierras al sur del País Valenciano, in Fumanal M. P. (ed.), Geoarqueología quaternari litoral: memorial María Pilar Fumanal. Universitat de València, València: 49-59.

AZUAR Ruiz R. \& GUTIÉRREZ Lloret S. 1999. - Formación y transformación de un espacio agrícola islámico en el sur del País Valenciano: el Bajo Segura (siglos IX-XIII), in BAZZANA A. (ed.), Castrum 5: Archéologie des espaces agraires méditerranéens au Moyen Âge: actes du colloque de Murcie (Espagne) tenu du 8 au 12 mai 1992. Casa de Velázquez, Madrid: 201-211. http:// hdl.handle.net/10045/18865

BAIST G. 1880. - Don Juan Manuel: El libro de la caza. Tomo XII. Halle, Saale. [1 ${ }^{\text {st }}$ ed. 1325].

BARCELÓ M. 1989. — El diseño de espacios irrigados en al-Andalus: un enunciado de principios generales, in CARA BARRIONUEVO L. (ed.), El agua en zonas áridas. Arqueología e historia. I: Hidráulica tradicional de la provincia de Almería. Instituto de Estudios Almerienses, Almería: 2013-2047.

BARrio BARrio J. A. 2008. - El campesinado en la frontera meridional del Reino de Valencia. Del hambre de tierra y el autoabastecimiento a la búsqueda del beneficio y la especulación, ss. XIII-XV. Actas del I Congreso Pautes de consum i nivel de vida al món rural medieval. University of Valencia, Valencia: 1-36.

Clemente Ramos J. 2001. - La evolución del medio natural en Extremadura. (c.1142-c. 1525), in Clemente Ramos J. (ed.), El medio natural en la España medieval: Actas del I congreso sobre ecohistoria e historia medieval. Universidad de Extremadura, Cáceres: 15-56.
Chapman A. \& Buck W. J. 1910. - La España inexplorada. INCAFO, Madrid, $456 \mathrm{p}$.

De Aragón E. 1766. - Arte cisoria, ó Tratado del arte de cortar del cuchillo. Biblioteca Real de San Lorenzo del Escorial, Madrid, 197 p.

Elvira Payán B. \& Doadrio Villarejo I. 1989. - Atlas provisional de los peces continentales de la provincia de Alicant. Mediterránea: serie de estudios biológicos (11): 9-34.

Escolano G. 1611. - Década primera de la historia de la insigne y coronada ciudad y reino de Valencia. Impr. Pedro Patricio Mey, Valencia, 692 p.

FERNÁNDEZ J. R. 2013. - Alytes obstetricans pertinax (Laurenti, 1768) - Sapo partero Común, in PARRONDO-CELDRÁN P. (coord.), Guía de los anfibios del sureste ibérico. Asociación Columbares, Murcia: 112-117.

FERNÁNDEZ M. \& Fidel L. 2004. — Anfibios y reptiles de Elche. La Matruca (14): 50-55.

FURIÓ A. 2001. — La domesticación del medio natural. Agricultura, ecología y economía en el País Valenciano en la Baja Edad Media, in Clemente Ramos J. (ed.), El medio natural en la España medieval: Actas del I congreso sobre ecohistoria e historia medieval. Universidad de Extremadura, Cáceres: 57-103.

GARRIDO-GARCía J. A. 2008. — Las comunidades de mamíferos del sureste de la península Ibérica: elementos para un análisis histórico. Galemys 20 (1): 3-46.

GONZÁlEZ F. 1981. - . Ecología y paisaje. Blume, Madrid, 250 p.

GonZÁlez L. M. \& Avellá J. F. 1989. — La extinción de la foca monje (Monachus monachus) en las costas mediterráneas de la Península Ibérica y propuesta de una estrategia de actuación. Ecología (3): 157-177.

GuTIÉRREZ J. 1789. - Libros de cetrería de El Principe y El Canciller. M. Tello, Madrid, 359 p.

GutiérREZ LloreT S. 1995. - El origen de la huerta de Orihuela entre los siglos VII y XI: una propuesta arqueológica sobre la explotación de las zonas húmedas del Bajo Segura. Arbor (593): 65-94.

Hinojosa Montalvo J. 1991. - Ermitas, conventos y cofradías en tierras de Alicante durante la Edad Media. Anales de la Universidad de Alicante. Historia Medieval (8): 257-300.

Hinojosa Montalvo J. 1992. - Aproximación a la ganadería alicantina en la Edad Media. Anales de la Universidad de Alicante. Historia Medieval (9): 161-178. https://doi.org/10.14198/medieval.1992-1993.9.10

Hinojosa MonTalvo J. 2006. - Jaime II y el esplendor de la corona de Aragón. Nerea, San Sebastián, 372 p.

JimÉnEZ PÉrEZ J. 2013. - El curioso caso del francolín: extinguido tras 600 años de presencia en España. Quercus (330): 16-23.

LÓPEZ DE Ayala P. 1959. - Libro de la caza de las aves. Texto integro en versión de J. Fradejas Lebrero. Castalia, Valencia, 243 p. (Coll. Odres Nuevos). [1st ed. 1386].

Lull V. 1984. - Ecología argárica. Anales de la Universidad de Murcia. Letras 43 (3-4): 21-47. http://hdl.handle.net/10201/12903

Maluquer J. \& Travé F. 1961. - Presencia y extinción del francolín en la península Ibérica e islas Baleares. Ardeola 7: 129-156.

MAS HERNÁNDEZ J. 1986. - La ictiofauna continental de la cuenca del río Segura. Evolución histórica y estado actual. Anales de Biología, Biología Ambiental 8 (2): 3-17.

Merino Álvarez A. 1981. - Geografía histórica del territorio de la actual provincia de Murcia desde la Reconquista por Jaime I de Aragón hasta la época presente. Academia Alfonso X el Sabio, Murcia, 571 p. [1 st ed. 1915].

Morales MuÑIZ A. 1996. - Algunas consideraciones teóricas en torno a la fauna como indicadora de espacios agrarios en la Prehistoria. Trabajos de Prehistoria 53 (2): 5-17.

Morales Muñiz A. \& Morales Muñiz D. C. 2001. — ¿De quién es este ciervo? Algunas consideraciones en torno a la fauna cinegética de la España medieval, in Clemente Ramos J. (ed.), El medio natural en la España medieval: Actas del I congreso sobre ecohistoria e historia medieval. Universidad de Extremadura, Cáceres: 383-406. 
Morales Muñiz A. \& Rofes J. 2008. - Early evidence for the Algerian hedgehog in Europe. Journal of Zoology 274 (1): 9-12. https://doi.org/10.1111/j.1469-7998.2007.00349.x

Morales Muñiz D. C. 2000. — La fauna exótica en la Península Ibérica: apuntes para el estudio del coleccionismo animal en el Medievo hispánico. Espacio, Tiempo y Forma. Serie III, Historia Medieval (13): 233-270. https://doi.org/10.5944/ etfiii.13.2000.5658

Nieto Fernández A. 1988. - Orihuela en sus documentos II. Economía y sociedad siglos XIV-XIX. Espigas, Murcia, $321 \mathrm{p}$.

Nores QuesADA C. \& LiESAU C. V. 1992. — La Zoología histórica como complemento de la Arqueozoología. El caso del zebro. Archaeofauna (1): 61-71.

OjeDA NieTO J. 2005. - Lobos en la Orihuela foral. Una visión del medio ambiente en los siglos XV al XVIII. Papeles de Geografía (41-42): 191-208.

OjedA NieTO J. 2007. - Montes y bosques de Orihuela en los siglos XVI y XVII. Investigaciones Geográficas (43): 121-139. https://doi.org/10.14198/INGEO2007.43.07

Ojeda Nieto J. \& Ojeda-Martínez C. 2008. — Relaciones ecológicas: aves, caza y pesca en Orihuela (ss. XVI-XVIII). Revista del Vinalopó (11): 149-160.

Pantoja A., Nohemi Sala M. T., García N., Ruiz Zapata B., Gil García M. J., Aranburu A., Arsuaga J. L. \& Casabó i BERNARD J. 2011. - Análisis paleontológico del yacimiento del Pleistoceno superior de Cova Foradada (Xábia, Alicante, España). Boletín de la Real Sociedad Española de Historia Natural. Sección geológica 105 (1-4): 53-66.

PARRA Villaescusa M. 2013. - Explotación agrícola en el sur del Reino de Valencia. El cultivo del arroz en Orihuela a finales de la Edad Media. XIII Premio Medievalismo. Medievalismo (23): 11-41.

Pleguezuelos J. M., Márquez R. \& Lizana M. (eds) 2002. - Atlas y Libro Rojo de los Anfibios y Reptiles de España. Dirección General de Conservación de la Naturaleza; Asociación Herpetologica Española, Madrid, $587 \mathrm{p}$.

Pujol J. A. 2012. - Recuperación de un topónimo geográfico relativo a la foca monje Monachus monachus (Hermann, 1779) en el litoral de Torrevieja (Alicante). Galemys (24): 71-73. https:// doi.org/10.7325/Galemys.2012.N04

Rabal SAURA G. 2006. - Creencias medicinales relacionadas con el mundo animal en el Campo de Cartagena. Revista Murciana de Antropología (13): 113-129.
Real Margalef C. 2012. - Aproximación metodológica y nuevos datos sobre los conjuntos arqueozoológicos del Magdaleniense superior de la Cova de les Cendres. Archivo de Prehistoria Levantina 29: 99-120.

Riquelme Cantal J. A. 1992. — La fauna de época Nazarí de "Macael Viejo", Macael (Almería). Cuadernos de Prehistoria y Arqueología de la Universidad de Granada 16: 453-460.

Sánchez Pérez A. J. \& Alonso de la Cruz R. C. 2004. - El territorio alicantino en las fuentes geográficas árabes medievales. Miscelánea Medieval Murciana (27-28): 103-124. https://doi. org/10.6018/j8151

Sánchez M. A. \& Esteve Selma M. A. 2000. — Los vertebrados terrestres de la región de Murcia: evolución histórica y especies amenazadas, in Calvo J. F., Esteve Selma M. A. \& López BerMÚDEZ F. (coord), Biodiversidad. Contribución a su conocimiento y conservación en la Región de Murcia. Universidad de Murcia, Servicio de Publicaciones, Murcia, 335 p.

SARMIENTO M. 1761. - Sobre el animal Zebra que se criaba en España. Colección de las obras del Pedro Sarmiento. Historia natural. Reynos animal y mineral, Tomo XII. [Unpublished Manuscript]. Museo de Pontevedra, Pontevedra, 172-213.

Terrón Albarrán M. 1983. - Los asnos salvajes, cebros y encebros en la España mediaval y Extremadura. Aspectos históricogeográficos y caza. Memorias de la Real Academia de Extremadura de las Letras y la Artes (1): 413-474.

TORRES FONTES J. 1974. — Ornitología Medieval Murciana. Revista Murgetana (39): 31-62.

TORRES FONTES J. 1981. — Los enemigos del hombre. Murgetana (61): 100-149.

Tórtola A. \& Tórtola M. 2015. - El topillo de cabrera y otros pequeños vertebrados extintos en la huerta de Murcia. Boletín de Asociación Cultural Paleontológica Murciana (8): 58-65.

VILAR J. B. 1977. - Historia de la ciudad de Orihuela: Los siglos XIV y XV en Orihuela. Patronato Ángel García Rogel, Obra Social de la Caja de Ahorros de Nuestra Señora de de Monserrate, Orihuela, $433 \mathrm{p}$

Villwock W. \& Planelles-Gomis M. 1999. - Peces Ciprinodontidos Ibéricos: Fartety Samaruc. Consellería de Medio Ambiente, Valenciana, Valencia, $357 \mathrm{p}$.

VON DEN DriesCh A. 1975. - Sobre los hallazgos de huesos de animales de Los Saladares, in ArTEaga O. \& SERnA M. R. (eds), Los Saladares-71. Noticiario arqueológico hispánico, Arqueología (3): 62-66.

Submitted on 26 January 2016 accepted on 27 September 2017; published on 29 December 2017. 